University of Nebraska - Lincoln

DigitalCommons@University of Nebraska - Lincoln

Faculty Papers and Publications in Animal

Science

Animal Science Department

2005

\title{
Evaluation of Grazing Alternate Summer and Fall Forages in Extensive Beef Cattle Production Systems
}

\author{
D. H. Shain \\ University of Nebraska-Lincoln \\ T. J. Klopfenstein \\ University of Nebraska-Lincoln, tklopfenstein1@unl.edu \\ R. A. Stock \\ University of Nebraska-Lincoln \\ B, A. Vieselmeyer \\ University of Nebraska-Lincoln \\ G. E. Erickson \\ University of Nebraska-Lincoln, gerickson4@unl.edu
}

Follow this and additional works at: https://digitalcommons.unl.edu/animalscifacpub

Part of the Animal Sciences Commons

Shain, D. H.; Klopfenstein, T. J.; Stock, R. A.; Vieselmeyer, B, A.; and Erickson, G. E., "Evaluation of Grazing Alternate Summer and Fall Forages in Extensive Beef Cattle Production Systems" (2005). Faculty Papers and Publications in Animal Science. 777.

https://digitalcommons.unl.edu/animalscifacpub/777

This Article is brought to you for free and open access by the Animal Science Department at DigitalCommons@University of Nebraska - Lincoln. It has been accepted for inclusion in Faculty Papers and Publications in Animal Science by an authorized administrator of DigitalCommons@University of Nebraska - Lincoln. 


\title{
7 \\ valuation of Grazing Alternate Summer and Fall Forages in Extensive Beef Cattle Production Systems ${ }^{1}$
}

\author{
D. H. SHAIN ${ }^{2}$, T. J. KLOPFENSTEIN ${ }^{3}$, R. A. STOCK ${ }^{4}$, B. A. VIESELMEYER \\ and G. E. ERICKSON, PAS \\ Department of Animal Science, University of Nebraska, Lincoln 68583-0908
}

\section{Abstract}

Studies across 5 yr involving 938 British-breed crossbred cattle (372 heifers, 566 steers) were used to evaluate the effects of grazing alternate summer and fall forages on slaughter breakeven cost of various beef production systems. Grazed summer forage combinations included 1) continuous brome, 2)brome and warm-season grasses, 3) brome and alfalfa or sudangrass, 4) brome and a monoculture of red clover, 5) red clover seeded in brome, 6) brome and Native Sandhills range, or 7) Sandhills range only. Grazed fall forages included 1) brome, 2) brome and turnips, 3) brome and rye, or 4) brome and cornstalks. Following grazing, the cattle were finished on a high-concentrate, corn-based finishing diet. The success

\footnotetext{
${ }^{1}$ A contribution of the University of Nebraska Agricultural Research Division, Lincoln. Journal Series No. 14911. This research was supported in part by funds provided through the Hatch Act.

'Land O'Lakes Purina Feed, Estherville, IA.

${ }^{3}$ To whom correspondence should be addressed: tklopfenstein1@unl.edu

${ }^{4}$ Present address: Cargill, Inc., Blair, NE.

${ }^{5}$ Present address: Curtis, NE.
}

of a grazing system was measured by slaughter breakeven cost analyses including all costs of production. The most consistent improvement in summer grazing $B W$ gain compared with continuous brome and the most desirable slaughter breakeven costs were observed for cattle grazing brome and warm-season grasses or brome and Sandhills range. Using alfalfa or sudangrass in grazing systems improved $(P<0.05)$ summer gains, but slaughter breakeven costs were greater $(P<0.05)$ compared with cattle grazing brome. Improved summer gains and reduced slaughter breakeven costs when grazing a monoculture of red clover or red clover seeded in brome were inconsistent among years compared with cattle grazing brome. Reductions in slaughter breakeven costs by grazing fall forages were observed in years with adequate moisture for forage growth. Forages that maximized grazing gain had the greatest effect on reducing slaughter breakeven cost.

(Key Words: Beef Cattle, Forages, Grazing, Production, Systems.)

\section{Introduction}

Most extensive beef production enterprises focus on individual seg- ments within the system and may not consider the economic impact that one segment has on the entire production system. Extensive beef production systems involve a backgrounding period during the winter and spring and a summer forage grazing period followed by finishing cattle in the feedlot. Lewis et al. (1990a) concluded that reducing inputs during the winter period offers some potential for lessening the cost of the production system. In addition, restriction of calf growth during the winter provides compensatory growth and reduces cost of gain during the summer (White et al., 1987; Lewis et al., 1990b). Using a high forage system is often economical, as cost of gain during the forage grazing period is typically less than that during the feeding of a high concentrate diet (Turgeon, 1984; Lewis et al., 1990a). However, research evaluating grazing different summer and fall forages on the total cost of the production system is limited. The objectives of this research were to evaluate the influence of different forage combinations on summer and fall beef cattle gains and to evaluate the effects of these combinations on the economics of the entire growing/finishing system. 


\section{Materials and Methods}

Data collected across 5 yr were used to evaluate grazing alternative forages during the summer and fall of each year. In each year, Britishbreed calves were purchased in the fall and shipped to the University of Nebraska, Agricultural Research and Development Center near Mead. All calves were allowed a 28$\mathrm{d}$ receiving and acclimation period followed by a wintering period with low cost inputs, as calves grazed cornstalk residue or were fed harvested forages. All calves were fed a protein supplement during the stalk grazing and harvested forage feeding periods, which supplied a minimum of $182 \mathrm{~g}$ of degradable protein and $136 \mathrm{~g}$ of metabolizable protein. In addition, all calves were allowed free access to a mineral supplement during both the stalk grazing and spring feeding periods. Following the winter and spring feeding periods, calves were assigned to grazing treatments. All forage pastures were located at the Agricultural Research and Development Center unless otherwise stated.

In the first year, 192 Britishbreed heifers $(199 \pm 2.4 \mathrm{~kg})$ were used. Heifers grazed irrigated cornstalks for $105 \mathrm{~d}$ and were fed ammoniated wheat straw for $53 \mathrm{~d}$. Straw was fed ad libitum in large round bales. Heifers received the same protein supplement during both the stalk grazing and ammoniated wheat straw feeding periods.

Following ammoniated wheat straw feeding, heifers were stratified by BW and assigned randomly, beginning on May 12, to one of four grazing treatments. Treatments included 1) continuously grazing smooth brome, 2) brome grazing until June 14 then grazing warm-season grass, 3 ) brome grazing until July 2 then alfalfa grazing, and 4) brome grazing until July 2 then grazing sudangrass. Poloxalene (Pfizer Inc., Exton, PA) was fed to cattle grazing

TABLE 1. Year 1 summer systems grazing area.

\begin{tabular}{|c|c|c|c|c|}
\hline Item & Treatment & ha/Head & Total ha & Days grazed \\
\hline \multicolumn{5}{|l|}{ August removal } \\
\hline Continuous brome & 1 & 0.4 & 19.2 & 110 \\
\hline Brome & 2 & 0.16 & 7.7 & 33 \\
\hline Warm season & & 0.24 & 11.5 & 77 \\
\hline Brome & 3 & 0.2 & 9.6 & 51 \\
\hline Alfalfa & & 0.2 & 9.6 & 59 \\
\hline Brome & 4 & 0.14 & 6.5 & 51 \\
\hline Sudangrass & & 0.26 & 12.7 & 59 \\
\hline
\end{tabular}

alfalfa to prevent bloat. Warm-season pastures were a mix of big and little bluestem. All grazing treatments ended on August 30, at which time one-half of the heifers from each grazing system were randomly allotted to continue grazing a combination of brome and warm-season pastures until December 8 . Grazing areas are listed in Table 1 .

Following grazing, heifers were placed in the feedlot and fed for $120 \mathrm{~d}$ (August removal groups) or $100 \mathrm{~d}$ (December removal groups). Heifers were adjusted to the final finishing diet in $21 \mathrm{~d}$ using four grain adaptation diets containing $45,35,25$ and $15 \%$ roughage (50:50 corn silage and alfalfa hay mixture, DM basis) fed for 3, 4, 7, and $7 \mathrm{~d}$, respectively. The final diet contained $82.5 \%$ of a corn-based concentrate, $7.5 \%$ roughage, $5 \%$ molasses-urea supplement, and 5\% dry supplement and was formulated (DM basis) to contain 12\% $\mathrm{CP}, 0.7 \% \mathrm{Ca}, 0.35 \% \mathrm{P}, 0.7 \% \mathrm{~K}$, $27.5 \mathrm{mg}$ of monensin (Elanco Animal Health, Indianapolis, IN) $/ \mathrm{kg}$, and $11.0 \mathrm{mg}$ of tylosin (Elanco Animal Health) $/ \mathrm{kg}$.

All heifers were implanted with Compudose ${ }^{\circledR}$ (Elanco Animal Health) before the grazing period and again at the beginning of the finishing phase. Initial and final BW for all phases of production (cornstalks, straw feeding, summer forage grazing, and fall forage grazing) were the average of BW taken on 2 consecutive d after $3 \mathrm{~d}$ of feed- ing a diet that was intake-limited to $2 \%$ of $\mathrm{BW}$. The diet consisted of $50 \%$ corn silage and 50\% alfalfa hay (DM basis). This combination was fed to reduce weight variation caused by fill. Final BW for the finishing phase were calculated from carcass weight adjusted to a common dressing percentage of $62 \%$. Heifers were fed in pens of 12 head each with two pens per forage system within both the August and December removal groups. All cattle were slaughtered when fat thickness, measured at the 12 th rib, was visually estimated at $1.02 \mathrm{~cm}$ and $50 \%$ of the cattle would grade Choice or better based on visual appraisal. Hot carcass weight and liver abscess scores were recorded at slaughter. Livers were scored for abscesses according to Brink et al. (1990). Fat thickness (12th rib) and quality and yield grade were obtained after carcasses were chilled for $48 \mathrm{~h}$.

In the second year, 180 Britishbreed heifers $(189 \pm 2.2 \mathrm{~kg})$ grazed irrigated and dryland cornstalks for $81 \mathrm{~d}$ and were fed ammoniated wheat straw for $69 \mathrm{~d}$. Heifers were blocked by BW and randomized to the summer grazing systems on May 4. Grazing systems were 1) continuous grazing of smooth brome until September 1; 2) brome and warm-season grass grazing until September 1; 3) grazing of smooth brome until November 23; 4) grazing of brome and red clover and return to the allotted brome pasture until November 23; 5) 
TABLE 2. Year 2 summer systems grazing area.

\begin{tabular}{lcccc} 
Item & Treatment & ha/Head & Total ha & Days grazed \\
\hline $\begin{array}{l}\text { September removal } \\
\text { Continuous brome }\end{array}$ & 1 & 0.4 & 12 & 120 \\
Brome & 2 & 0.16 & 4.8 & 30 \\
Warm season & & 0.24 & 7.2 & 90 \\
November removal & & & & \\
Continuous brome & 3 & 0.64 & 19.6 & 204 \\
Brome & 4 & 0.52 & 15.7 & 102 \\
Clover & & 0.4 & 12 & 102 \\
Brome & 5 & 0.44 & 13 & 90 \\
Clover & & 0.4 & 12 & 60 \\
Turnips & & 0.28 & 8.4 & 54 \\
Brome & 6 & 0.32 & 9.7 & 68 \\
Warm season & & 0.24 & 7.2 & 74 \\
Red clover & & 0.28 & 8.4 & 62 \\
\end{tabular}

brome, red clover, and turnip grazing until November 23; and 6) grazing of brome, warm-season grass pastures, red clover, and brome again until November 23. Forage systems ended either September 1 or November 23, at which time the cattle were placed in the feedlot for finishing. Forage systems were designed to utilize one or a combination of forages. Rotation from forage to forage was variable and dependent on forage quantity and quality, yet the cattle were provided with the most optimum forage at all times. Days of grazing and assigned areas for each forage within each system are listed in Table 2 .

Red clover was seeded simultaneously with oats in the spring. Oats were harvested as hay in late June. Cattle began grazing red clover on July 6. Warm-season grass pastures were a mix of big and little bluestem, Indian grass, switchgrass, and sideoats grama; grazing began June 8. Turnips were broadcast-seeded following one tillage of wheat stubble in late July. Grazing of turnips began October 4.

Heifers in September removal groups (Treatments 1 and 2) were finished in the feedlot for an average of $106 \mathrm{~d}$ with the heifers in the
November removal groups fed for an average of $87 \mathrm{~d}$. All heifers were adjusted to and fed a final finishing diet similar to that offered in the first year. All heifers were implanted with Compudose ${ }^{\circledR}$ before the grazing period and were implanted again at the beginning of the finishing phase. Weighing procedures, slaughter scheduling, final finishing BW, and carcass measurements were similar to those in the first year. Heifers were fed in pens of 15 head each with two pens per forage system.

In the third year, 182, medium frame, British-breed steers (202 \pm $4.9 \mathrm{~kg}$ ) grazed irrigated and dryland cornstalks for $104 \mathrm{~d}$ and were fed ammoniated wheat straw for 69 d. On May 5, steers were blocked by BW and assigned to one of seven forage grazing systems: 1) continuously grazing smooth brome until September 15, 2) grazing brome or warm-season grasses until September 15, 3) grazing brome or a mixture of warm- and cool-season grasses until September $15,4)$ brome grazing until November 12, 5) brome grazing until September 15 followed by turnip grazing until November 12, 6) grazing brome or warm-season grasses until September 15 followed by turnip grazing until November 12, and 7) grazing brome or a mixture of warm- and cool-season grasses until September 15 followed by turnip grazing until November 12. Days of grazing and assigned areas for each system are listed in Table 3. Cattle in systems using a combination of forages were rotated based on forage quality and quantity to ensure that the most optimum forage was available at all times. Warm-season grass pastures were a mix of big and little bluestem, Indian grass, switchgrass, and sideoats grama. The mixture of warm- and cool-season grass pastures was predominantly switchgrass, big bluestem, and smooth brome. Grazing of warm-season and the mixture of warm- and cool-season grass pastures began on June 3. Turnips were broadcast-seeded following one disk tillage of wheat stubble in late July. Grazing of turnips began on October 13.

Following grazing, steers were fed for an average of 101 and $84 \mathrm{~d}$ for the September and November removal grazing groups, respectively. All steers were adjusted to and fed a final finishing diet similar to that found in the first year. All steers were implanted with Compudose ${ }^{\circledR}$ before the grazing period and were implanted again at the beginning of the finishing phase. Weighing procedures, slaughter scheduling, final finishing BW, and carcass measurements were similar to those in the first year. Steers were fed in pens of 13 head each with two pens per forage system.

In the fourth year, 192 mediumframed, British-breed steers (221 \pm $2.8 \mathrm{~kg}$ ) grazed irrigated cornstalks for $58 \mathrm{~d}$ and were fed alfalfa and grass hay for $99 \mathrm{~d}$. On May 7, steers were blocked by BW and assigned to one of eight grazing systems: 1) continuously grazing brome until September 7, 2) rotational grazing brome until September 7,3 ) rotational grazing of red clover interseeded in brome until September 7,4$)$ grazing brome or 
TABLE 3. Year 3 summer systems grazing area.

\begin{tabular}{lccrr} 
Item & Treatment & ha/Head & Total ha & Days grazed \\
\hline September removal & & & & \\
Continuous brome & 1 & 0.4 & 10.4 & 133 \\
Brome & 2 & 0.16 & 4.2 & 44 \\
Warm season & & 0.24 & 6.2 & 89 \\
Brome & 3 & 0.16 & 4.2 & 59 \\
Warm-/cool-season mix & & 0.24 & 6.2 & 74 \\
November removal & & & & \\
Continuous brome & 4 & 0.66 & 17.3 & 191 \\
Brome & 5 & 0.48 & 12.5 & 160 \\
Turnips & & 0.25 & 6.4 & 31 \\
Brome & 6 & 0.24 & 6.2 & 71 \\
Warm-season grass & & 0.24 & 6.2 & 89 \\
Turnips & & 0.25 & 6.4 & 31 \\
Brome & 7 & 0.24 & 6.2 & 86 \\
Warm-/cool-season mix & & 0.24 & 6.2 & 74 \\
Turnips & & 0.25 & 6.4 & 31 \\
\hline
\end{tabular}

warm-season grasses until September 7,5$)$ grazing brome or native Sandhills range until September 7, 6) grazing native Sandhills range until September 7, 7) grazing brome or warm-season grasses until September 7 with brome or turnip/ rye grazing until November 12 , and 8) grazing brome until September 7 with brome or turnip/rye grazing until November 12. Native Sandhills range pasture was located approximately $30 \mathrm{~km}$ north of North Platte, Nebraska. Days of grazing and assigned areas for each forage within each system are listed in Table 4 .

Cattle in the red clover/bromegrass system grazed a seven-paddock rotation. Six of these paddocks were offered in the first three years following red clover seeding, two paddocks each. The seventh paddock, a monoculture of brome, was twice the size of the other paddocks and was used as an area for animals to graze while allowing appropriate rest for the red clover/ bromegrass paddocks. Cattle were rotated among paddocks every $5 \mathrm{~d}$. Cattle in the rotational bromegrass system served as the control group for the red clover and bromegrass system with paddock size, paddock number, and rotation time the same as the red clover and bromegrass system.

Cattle in systems using a combination of forages (excluding red clover and bromegrass) were rotated based on forage quality and quantity to ensure that the highest quality forage was available at all times.
Warm-season grass pastures were a mix of big and little bluestem, Indian grass, switchgrass, and sideoats grama. Grazing of warm-season grass pastures began on June 10. Turnips and rye were drilled into wheat stubble following a onedisked tillage of wheat stubble in late July. Grazing of turnips and rye began on October 2 , and cattle were allowed access to turnips and rye simultaneously.

Following grazing, steers were fed for an average of 98 and $93 \mathrm{~d}$ for the September and November removal grazing groups, respectively. All steers were adjusted to and fed a final finishing diet similar to those in the first year. All steers were implanted with Compudose ${ }^{\circledR}$ before the grazing period and were implanted again at the beginning of the finishing phase. Weighing procedures, slaughter scheduling, final finishing weights, and carcass measurements were similar to the first year. Steers were fed in pens of 12 head each with two pens per forage system.

In the fifth year, 192 mediumframed, British-breed steers (215 \pm $4.1 \mathrm{~kg}$ ) grazed irrigated or dryland cornstalks for $98 \mathrm{~d}$ and were fed al-

TABLE 4. Year 4 summer systems grazing area.

\begin{tabular}{lcccc} 
Item & Treatment & ha/Head & Total ha & Days grazed \\
\hline $\begin{array}{l}\text { September removal } \\
\text { Continuous brome }\end{array}$ & 1 & 0.4 & 9.6 & 129 \\
Rotational brome & 2 & 0.4 & 9.6 & 129 \\
Red clover/brome & 3 & 0.3 & 7.2 & 141 \\
Brome & & 0.1 & 2.4 & \\
Brome & 4 & 0.16 & 3.8 & 34 \\
Warm-season grass & & 0.24 & 5.8 & 95 \\
Brome & 5 & 0.16 & 3.8 & 34 \\
Sandhills range & & 1.98 & 47.6 & 95 \\
Sandhills range & 6 & 2.76 & 66.4 & 129 \\
November removal & & & & \\
Brome & 7 & 0.24 & 5.8 & 54 \\
Warm-season grass & & 0.24 & 5.8 & 95 \\
$\quad \begin{array}{l}\text { Turnips/rye } \\
\text { Brome }\end{array}$ & & 0.25 & 6.0 & 40 \\
$\quad$ Turnips/rye & 8 & 0.48 & 11.6 & 149 \\
& & 0.25 & 6.0 & 40 \\
\end{tabular}


TABLE 5. Year 5 summer systems grazing area.

\begin{tabular}{lcccc} 
Item & Treatment & ha/Head & Total ha & Days grazed \\
\hline $\begin{array}{l}\text { September removal } \\
\text { Continuous brome }\end{array}$ & 1 & 0.4 & 9.6 & 97 \\
Rotational brome & 2 & 0.4 & 9.6 & 97 \\
Red clover/Brome & 3 & 0.3 & 7.2 & 97 \\
Brome & & 0.1 & 2.4 & \\
Brome & 4 & 0.16 & 3.8 & 38 \\
Warm-season grass & & 0.24 & 5.8 & 74 \\
Brome & 5 & 0.16 & 3.8 & 31 \\
Sandhills range & & 1.98 & 47.6 & 94 \\
Sandhills range & 6 & 2.76 & 66.4 & 125 \\
November removal & & & & \\
Brome & 7 & 0.24 & 5.8 & 31 \\
Sandhills range & & 1.98 & 5.8 & 94 \\
Rye or cornstalks & & 0.4 & 9.6 & 68 \\
Brome & 8 & 0.48 & 11.6 & 125 \\
Rye or cornstalks & & 0.4 & 9.6 & 68
\end{tabular}

falfa and grass hay for $76 \mathrm{~d}$. On May 5 , steers were blocked by BW and randomly assigned to one of eight forage grazing systems: 1) continuous brome grazing until August 10 ; 2) rotational brome grazing until August 10; 3) grazing of rotational red clover interseeded in brome until August 10; 4) grazing of brome or warm-season grasses until August 25; 5) grazing of brome or native Sandhills range until September 13; 6) grazing native Sandhills range until September 7; 7) grazing brome or native Sandhills range until September 7 with brome, rye, or cornstalk grazing until November 17; and 8) grazing brome until September 7 with brome, rye, or cornstalk grazing until November 17. Native Sandhills range pasture was the same as that used in the fourth year. Days of grazing and assigned area for each forage within each system are listed in Table 5.

Cattle in the red clover and bromegrass system were managed the same as in the fourth year. Cattle in systems using a combination of forages (excluding red clover and brome) were rotated based on forage quality and quantity to en- sure optimum forage availability at all times. Warm-season grass pastures were a mix of big and little bluestem, Indian grass, switchgrass, and sideoats grama. Grazing of warm-season grass pastures began on June 12 . Rye was drilled into wheat stubble in early August. Cornstalks were made available following the harvest of high moisture corn. Cattle grazing cornstalks received $0.8 \mathrm{~kg}$ per head of a protein supplement daily. Grazing of rye and cornstalks began on October 12 .

Following grazing, steers were implanted with Revalor-S ${ }^{\circledR}$ (HoechstRoussel, Somerville, NJ) and were fed for an average of 107, 79, and $61 \mathrm{~d}$ for grazing treatments ending in August, September, and November, respectively. All steers were adjusted to and fed a final finishing diet similar to the first year. All steers were implanted with Compudose ${ }^{\circledR}$ before the grazing period. Weighing procedures, slaughtering schedule, final finishing BW, and carcass measurements were similar to the first year. Steers were fed in pens of 12 head each with two pens per forage system.
Statistical and Economic Analysis. Slaughter breakeven cost was used as the measure of success of each system and included all input costs. Data were analyzed as a completely randomized design using the GLM procedures of SAS ${ }^{\circledR}$ (SAS Inst., Inc., Cary, NC) with grazing treatment as the main effect and cattle in a feedlot pen as the observation unit for statistical analysis (pasture not replicated). Breakeven correlation coefficients for amount of gain achieved during the winter, summer grazing, combined summer and fall grazing, and finishing periods were determined to evaluate which period, within each system, had the most influence on breakeven cost (SAS Inst., Inc., Cary, NC).

\section{Results}

Year 1. Heifers grazing brome then warm-season grasses (Treatment 2) had the greatest BW gains $(P<0.05)$ compared with other grazing treatments (Table 6).

In addition, heifers grazing brome then either alfalfa or sudangrass had greater gains $(P<0.05)$ compared with heifers grazing only brome. However, summer grazing BW gains were less than expected and were probably due to less rainfall experienced during the summer.

Heifers grazing brome then warm-season grass until August 30 entered the feedlot at heavier BW $(P<0.05)$ compared with other treatments. However, during the finishing phase heifers in the brome, brome and alfalfa, or brome and sudangrass August removal grazing treatments made compensatory gains resulting in no difference $(P=$ 0.05 ) in final finishing BW. Heifers on the brome and warm-season grazing treatment consumed less feed $(P<0.05)$ than heifers grazing only brome or brome and sudangrass. No differences in gain, feed efficiency, or carcass measurements were observed. 
TABLE 6. In the first year, summer and fall grazing performance and subsequent finishing performance for heifers grazing different forage combinations.

\begin{tabular}{|c|c|c|c|c|c|}
\hline Item & $\begin{array}{l}\text { Continuous } \\
\text { brome }\end{array}$ & $\begin{array}{l}\text { Brome, warm- } \\
\text { season grass }\end{array}$ & $\begin{array}{l}\text { Brome, } \\
\text { alfalfa }\end{array}$ & $\begin{array}{c}\text { Brome, } \\
\text { sudan-grass }\end{array}$ & SEM \\
\hline Initial BW, kg & 199 & 198 & 201 & 197 & 1.9 \\
\hline \multicolumn{6}{|l|}{$A D G, k g$} \\
\hline Winter & 0.39 & 0.39 & 0.37 & 0.39 & 0.01 \\
\hline Summer & $0.44^{x}$ & $0.60^{y}$ & $0.53^{\mathrm{z}}$ & $0.54^{z}$ & 0.01 \\
\hline \multicolumn{6}{|c|}{ Summer grazing system ${ }^{a}$} \\
\hline Finishing DMI, kg/d & $11.55^{\mathrm{x}}$ & $10.66^{y}$ & $10.90^{x y}$ & $11.38^{\mathrm{x}}$ & 0.17 \\
\hline ADG, $\mathrm{kg}$ & 1.60 & 1.51 & 1.58 & 1.56 & 0.06 \\
\hline Gain:feed & 0.139 & 0.141 & 0.145 & 0.137 & 0.003 \\
\hline Fat depth, cm & 1.24 & 1.19 & 1.22 & 1.02 & 0.08 \\
\hline Quality grade ${ }^{\mathrm{b}}$ & 19.5 & 19.5 & 18.9 & 19.3 & 0.4 \\
\hline Yield grade & 2.5 & 2.4 & 2.5 & 2.4 & 0.1 \\
\hline \multicolumn{6}{|l|}{ Fall grazing system ${ }^{c}$} \\
\hline Initial fall BW, kg & $320^{x}$ & $341^{y}$ & $329^{x}$ & $333^{x}$ & 3.6 \\
\hline Fall ADG, kg & 0.44 & 0.33 & 0.39 & 0.34 & 0.04 \\
\hline Finishing DMl, kg/d & 11.33 & 11.21 & 11.14 & 11.62 & 0.15 \\
\hline $\mathrm{ADG}, \mathrm{kg}$ & 1.29 & 1.35 & 1.29 & 1.37 & 0.06 \\
\hline Gain:feed & 0.114 & 0.121 & 0.116 & 0.117 & 0.005 \\
\hline Fat depth, $\mathrm{cm}$ & 1.12 & 1.07 & 1.02 & 1.14 & 0.05 \\
\hline Quality grade ${ }^{b}$ & 19.2 & 19.3 & 18.6 & 19.4 & 0.2 \\
\hline Yield grade & 2.5 & 2.3 & 2.5 & 2.5 & 0.1 \\
\hline
\end{tabular}

Heifers grazing brome and warmseason grasses during the summer entered the fall grazing period with heavier weights than heifers on other treatments. However, the drought conditions reduced the quantity and quality of forage available during the fall. Therefore, to achieve the greatest gains possible, heifers were allowed access to all pastures containing either brome or warm-season grasses. No difference in ADG during the fall grazing period were observed with gains during this period less than desired $(<0.45 \mathrm{~kg} / \mathrm{d})$. The poor performance during the fall grazing period resulted in no difference in BW among treatments entering the finishing phase.

No differences in DMI, ADG, feed efficiency, or carcass measurements were noted during the finishing phase for heifers in the fall grazing system. However, heifers in the brome and warm-season, December removal grazing treatment had heavier final BW $(P<0.05)$ compared with heifers from the brome, December removal grazing group.

No difference in slaughter breakeven cost was noted for August removal heifers grazing only brome, brome and warm-season grasses, or brome and sudangrass (Table 7). However, heifers grazing brome and warm-season grasses had the most desirable slaughter breakeven cost compared with other August removal treatments. Extending the grazing period into the fall increased $(P<0.05)$ slaughter breakeven costs for each December removal grazing system compared with similar grazing systems removed in August.

Correlation coefficients indicated that the amount of $\mathrm{BW}$ gain achieved during the finishing period had the most effect on reducing slaughter breakeven cost $(-0.73)$. The amount of gain achieved during the fall grazing period had a positive effect on breakeven cost (0.70).

Year 2. Abundant rainfall during the summer offered excellent quality and quantity of forage available for all grazing systems in the second year. Therefore, ADG differences among treatments were few. However, heifers grazing brome, warm-season grasses, and red clover (Treatment 6) had greater ADG $(P<0.05)$ compared with heifers on all other treatments except those grazing brome and warm-season grasses (Table 8).

Daily gains during the fall grazing period for November removal systems were different $(P<0.05)$. Cattle that were in the brome, 
TABLE 7. In the first year, total system economics of heifers grazing different forage combinations.

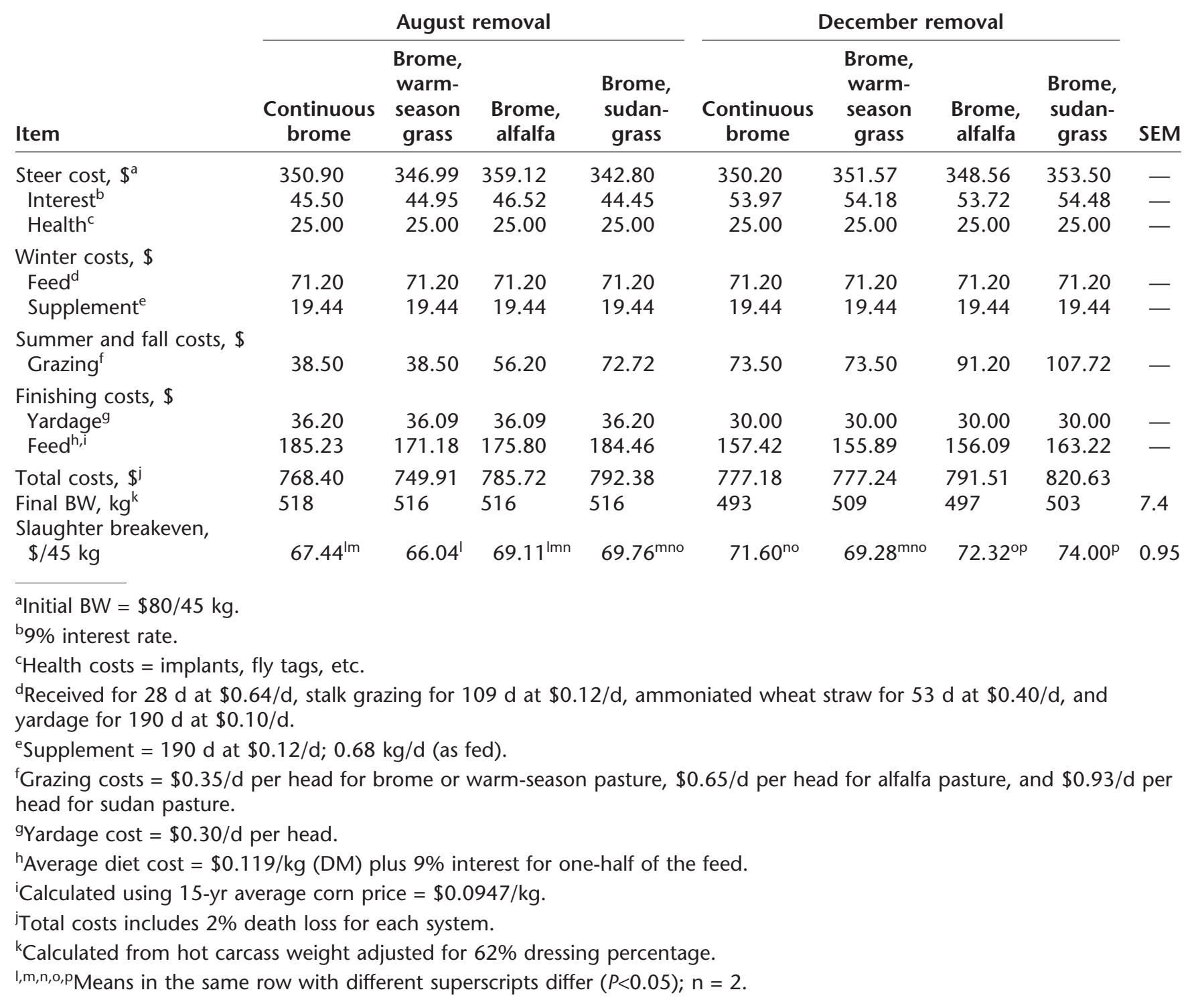

warm-season, red clover system, which had the greatest ADG until August 31, had the least ADG $(P<0.05)$ during fall grazing, and cattle grazing only brome and red clover had the greatest ADG $(P<0.05)$. Utilizing alternative fall forages, such as red clover and turnips, improved ADG $(P<0.05)$ above the brome control treatment during the fall grazing period.

During the finishing period, DMI varied among treatments. Heifers on the brome grazing, November removal system had the least ADG
$(P<0.05)$ and gain to feed ratio $(\mathrm{G}: \mathrm{F})(P<0.05)$ during the finishing period compared with other treatments. Final finishing BW were greater $(P<0.05)$ for November removal systems for heifers grazing brome and red clover; brome, red clover, and turnips; or brome, warm-season grasses, and red clover compared with heifers in the September and November removal systems grazing only brome. No differences in fat thickness or yield grade were noted among treatments. Heifers in the brome graz- ing, November removal system had lesser quality grades $(P<0.05)$ compared with heifers grazing brome and red clover in the November removal system.

Heifers in the November removal system that grazed brome and red clover (Treatment 4) numerically had the most desirable slaughter breakeven cost (Table 8). However, heifers in the November removal systems that grazed brome, red clover, and turnips or brome, warmseason grasses and red clover (Treatments 5 and 6, respectively) had 
TABLE 8. In the second year, grazing performance and subsequent finishing performance for heifers grazing different forage combinations.

\begin{tabular}{|c|c|c|c|c|c|c|c|}
\hline \multirow[b]{2}{*}{ Item } & \multicolumn{2}{|c|}{ Summer removal } & \multicolumn{4}{|c|}{ Fall removal } & \multirow[b]{2}{*}{ SEM } \\
\hline & $\begin{array}{c}\text { Continuous } \\
\text { brome }\end{array}$ & $\begin{array}{c}\text { Brome, } \\
\text { warm- } \\
\text { season grass }\end{array}$ & $\begin{array}{c}\text { Continuous } \\
\text { brome }\end{array}$ & $\begin{array}{l}\text { Brome, } \\
\text { red } \\
\text { clover }\end{array}$ & $\begin{array}{l}\text { Brome, } \\
\text { red clovern } \\
\text { turnips }\end{array}$ & $\begin{array}{c}\text { Brome, } \\
\text { warm-season } \\
\text { grass, red clover }\end{array}$ & \\
\hline Initial BW, kg & 187 & 189 & 193 & 188 & 188 & 187 & 2.2 \\
\hline \multicolumn{8}{|l|}{ ADG, $\mathrm{kg}$} \\
\hline Winter & 0.39 & 0.40 & 0.35 & 0.38 & 0.37 & 0.39 & 0.01 \\
\hline Summer & $0.88^{\mathrm{uv}}$ & $0.94^{\mathrm{vx}}$ & $0.84^{\mathrm{u}}$ & $0.90^{\mathrm{uv}}$ & $0.91^{\mathrm{uv}}$ & $0.99^{x}$ & 0.03 \\
\hline Fall & - & - & $0.47^{\mathrm{u}}$ & $0.76^{\vee}$ & $0.61^{x}$ & $0.38^{y}$ & 0.02 \\
\hline Total grazing & $0.88^{\mathrm{uv}}$ & $0.94^{\mathrm{u}}$ & $0.69^{x}$ & $0.84^{v y}$ & $0.79^{y z}$ & $0.74^{x z}$ & 0.02 \\
\hline \multicolumn{8}{|c|}{ Finishing performance ${ }^{\mathrm{a}}$} \\
\hline DMI, kg/d & $11.5^{\mathrm{uv}}$ & $11.4^{\mathrm{u}}$ & $11.9^{\mathrm{ux}}$ & $12.2^{\mathrm{x}}$ & $12.1^{\mathrm{vx}}$ & $12.3^{x}$ & 0.17 \\
\hline $\mathrm{ADG}, \mathrm{kg}$ & $1.37^{u}$ & $1.35^{\mathrm{u}}$ & $1.18^{v}$ & $1.37^{\mathrm{u}}$ & $1.40^{\mathrm{u}}$ & $1.44^{\mathrm{u}}$ & 0.03 \\
\hline Gain:feed & $0.119^{\mathrm{u}}$ & $0.118^{\mathrm{u}}$ & $0.099^{v}$ & $0.112^{\mathrm{u}}$ & $0.116^{\mathrm{u}}$ & $0.117^{u}$ & 0.003 \\
\hline \multicolumn{8}{|l|}{ Carcass data } \\
\hline Fat depth, $\mathrm{cm}$ & 1.12 & 1.02 & 0.99 & 1.12 & 1.09 & 1.04 & 0.05 \\
\hline Quality grade & $18.6^{\mathrm{uv}}$ & $18.5^{\mathrm{uv}}$ & $18.4^{\mathrm{u}}$ & $19.2^{v}$ & $19.0^{\mathrm{uv}}$ & $18.7^{\mathrm{uv}}$ & 0.2 \\
\hline Yield grade & 2.3 & 2.2 & 2.2 & 2.5 & 2.5 & 2.3 & 0.1 \\
\hline \multicolumn{8}{|c|}{ Slaughter breakeven ${ }^{\mathrm{b}}$, } \\
\hline$\$ / 45 \mathrm{~kg}$ & $64.47^{u}$ & $63.52^{\mathrm{uv}}$ & $67.41^{x}$ & $61.35^{y}$ & $62.38^{\text {vy }}$ & $62.61^{\text {vy }}$ & 0.57 \\
\hline
\end{tabular}

similar slaughter breakeven costs compared with November removal heifers that grazed brome and red clover. Heifers in the September removal systems grazing brome or brome and warm-season grasses had intermediate slaughter breakeven costs, and heifers in the November removal system that grazed only brome had the greatest $(P<0.05)$ slaughter breakeven cost.

Correlation coefficients indicated that the amount of BW gain achieved during the summer $(\mathrm{r}=$ $-0.46)$ or the combined summer and fall grazing periods $(\mathrm{r}=-0.44)$ had the most effect on reducing slaughter breakeven cost. In addition, the final BW for each system also had an affect on reducing slaughter breakeven cost $(\mathrm{r}=$ -0.89 ).

Year 3. The summer again provided abundant rainfall and mild temperatures, making conditions favorable for brome growth, which was different from most years. Gains for steers on the continuous brome grazing, November removal system (Treatment 4) were greater $(P<0.05)$ from May to September than for all other systems (Table 9). This is most likely due to a combination of less stocking density and favorable weather for cool-season grasses; steers on this treatment were probably able to graze a greater-quality regrowth continuously throughout the summer. However, steers in other systems were probably limited in the amount of regrowth available because of a greater stocking density and by weather less favorable to growth by warm-season grasses.

For the remainder of the systems (excluding the brome grazing, November removal system), steers grazing brome and warm-season grasses (Treatments 2 and 6) had the next greatest ADG $(P<0.05)$ followed by steers grazing brome
(Treatment 5) or brome and a mixture of warm- and cool-season grasses (Treatments 3 and 7). Steers grazing continuous brome (Treatment 1) exhibited the least ADG $(P<0.05)$ during the summer grazing period. Steers in the continuous brome grazing, November removal system (Treatment 4 ) had greater $(P<0.05)$ ADG than other systems (Treatments 5,6 , or 7 ) from September 15 to November 12 (Table 9).

Differences among treatments for ADG, DMI, and feed efficiency varied. No differences were noted in carcass measurements (fat thickness, yield grade, or quality grade) among treatments, indicating that all steers were finished to a similar endpoint. Final BW was greatest $(P<0.05)$ for steers on the brome grazing, November removal system and the brome, warm-season grass, and turnip grazing, November re- 
TABLE 9. In the third year, grazing performance and subsequent finishing performance for steers grazing different forage combinations.

\begin{tabular}{|c|c|c|c|c|c|c|c|c|}
\hline \multirow[b]{2}{*}{ Item } & \multicolumn{3}{|c|}{ September removal } & \multicolumn{4}{|c|}{ November removal } & \multirow[b]{2}{*}{ SEM } \\
\hline & $\begin{array}{l}\text { Continuous } \\
\text { brome }\end{array}$ & $\begin{array}{l}\text { Brome, } \\
\text { warm- } \\
\text { season } \\
\text { grass }\end{array}$ & $\begin{array}{c}\text { Brome, } \\
\text { warm- and } \\
\text { cool-season } \\
\text { mix }\end{array}$ & Brome & $\begin{array}{l}\text { Brome, } \\
\text { turnips }\end{array}$ & $\begin{array}{c}\text { Brome, } \\
\text { warm-season, } \\
\text { grass, } \\
\text { turnips }\end{array}$ & $\begin{array}{l}\text { Brome, } \\
\text { warm-, and } \\
\text { cool-season } \\
\text { mix, turnips }\end{array}$ & \\
\hline Initial BW, kg & 208 & 203 & 203 & 199 & 198 & 207 & 202 & 4.9 \\
\hline \multicolumn{9}{|l|}{ ADG, kg } \\
\hline Winter & 0.21 & 0.21 & 0.24 & 0.23 & 0.25 & 0.21 & 0.22 & 0.02 \\
\hline Summer & $0.74^{v}$ & $0.90^{x}$ & $0.84^{y}$ & $0.98^{z}$ & $0.79^{v y}$ & $0.92^{v}$ & $0.84^{y}$ & 0.01 \\
\hline Fall & - & - & - & $0.88^{v}$ & $0.64^{x}$ & $0.56^{x}$ & $0.58^{x}$ & 0.02 \\
\hline Total grazing & $0.74^{v}$ & $0.90^{x}$ & $0.84^{y}$ & $0.95^{x}$ & $0.74^{v}$ & $0.81^{y}$ & $0.76^{v}$ & 0.01 \\
\hline \multicolumn{9}{|c|}{ Finishing performance ${ }^{a}$} \\
\hline $\mathrm{DMI}, \mathrm{kg} / \mathrm{d}$ & $12.04^{\mathrm{vx}}$ & $11.68^{v}$ & $12.54^{x}$ & $12.66^{x}$ & $12.02^{\mathrm{vx}}$ & $12.79^{x}$ & $11.59^{v}$ & 0.23 \\
\hline $\mathrm{ADG}, \mathrm{kg}$ & $1.63^{\mathrm{vxy}}$ & $1.70^{\mathrm{vx}}$ & $1.61^{\mathrm{vxy}}$ & $1.49^{v y}$ & $1.52^{\mathrm{vxy}}$ & $1.72^{x}$ & $1.44^{y}$ & 0.06 \\
\hline Gain:feed & $0.136^{\mathrm{vx}}$ & $0.145^{\vee}$ & $0.128^{x y}$ & $0.117^{\mathrm{yz}}$ & $0.127^{v x}$ & $0.134^{v x}$ & $0.125^{x z}$ & 0.005 \\
\hline \multicolumn{9}{|l|}{ Carcass data } \\
\hline Fat depth, cm & 0.91 & 0.96 & 0.89 & 0.96 & 0.91 & 1.02 & 0.79 & 0.08 \\
\hline Quality grade & 18.0 & 18.1 & 18.5 & 18.5 & 18.2 & 18.7 & 18.3 & 0.2 \\
\hline Yield grade & $2.3^{\mathrm{vx}}$ & $2.4^{\mathrm{vx}}$ & $2.3^{v x}$ & $2.5^{\mathrm{vx}}$ & $2.3^{v x}$ & $2.6^{v}$ & $2.1^{x}$ & 0.1 \\
\hline \multicolumn{9}{|c|}{ Slaughter breakeven ${ }^{\mathrm{b}}$} \\
\hline$\$ / 45 \mathrm{~kg}$ & $69.71^{v}$ & $65.40^{x y}$ & $67.81^{v x}$ & $63.69^{y}$ & $67.25^{\mathrm{vx}}$ & $65.33^{x y}$ & $68.09^{v x}$ & 0.80 \\
\hline
\end{tabular}

moval systems (Treatments 4 and 6 , respectively).

No advantage was noted in breakeven cost between grazing systems ending in September vs November (Table 9). Steers in the brome grazing, November removal system and steers grazing brome and warm-season grasses until September 15 or grazing turnips until November 12 had the most desirable breakeven costs. Correlation coefficients between slaughter breakeven cost and summer BW gain (-0.85), combined summer and fall gain $(-0.69)$, and feedlot gain (0.13) indicated that summer grazing gain and combined summer and fall gain had the most effect on breakeven cost. Finishing gain had no effect on reducing breakeven costs.

Combined Years 4 and 5. Data from similar grazing systems (Treatments $1,2,3,4,5$, and 6) in the fourth and fifth years were pooled
(Table 10). Steers grazing brome and Sandhills range or only Sandhills range had greater $(P<0.05)$ grazing ADG compared with that of steers on other systems. In addition, steers grazing brome and warm-season grasses had greater $(P<0.05) \mathrm{BW}$ gains compared with cattle grazing only brome, continuously or rotationally. During the finishing period, DMI among systems varied. However, there were no differences in ADG or G:F among systems, indicating that previous summer grazing treatments had no influence on finishing performance. No differences in yield grade were observed among systems. However, steers rotationally grazing brome had more fat thickness $(P<0.05)$ and a greater $(P<0.05)$ quality grade compared with steers grazing brome and Sandhills range.

Steers grazing brome and Sandhills range had more desirable
$(P<0.05)$ slaughter breakeven costs compared with steers grazing brome either continuously or rotationally (Table 10). Steers grazing brome continuously had the least desirable $(P<0.05)$ slaughter breakeven cost compared with other treatments.

In the fourth year, breakeven cost correlations for summer BW gain $(-0.74)$, the combined summer and fall gain (-0.39), and feedlot gain $(-0.72)$ indicated that summer grazing gain and feedlot gain had the most effect on breakeven cost. In the fifth year, correlation coefficients for summer BW gain $(-0.81)$, combined summer and fall gain $(-0.34)$, and feedlot gain (0.23) indicated that grazing gains had the most effect on breakeven cost.

The amount of red clover in red clover and brome paddocks was variable. In the fourth year, it was 
TABLE 10. Common treatments for Years 4 and 5. Grazing performance and subsequent finishing performance for steers grazing different forage combinations.

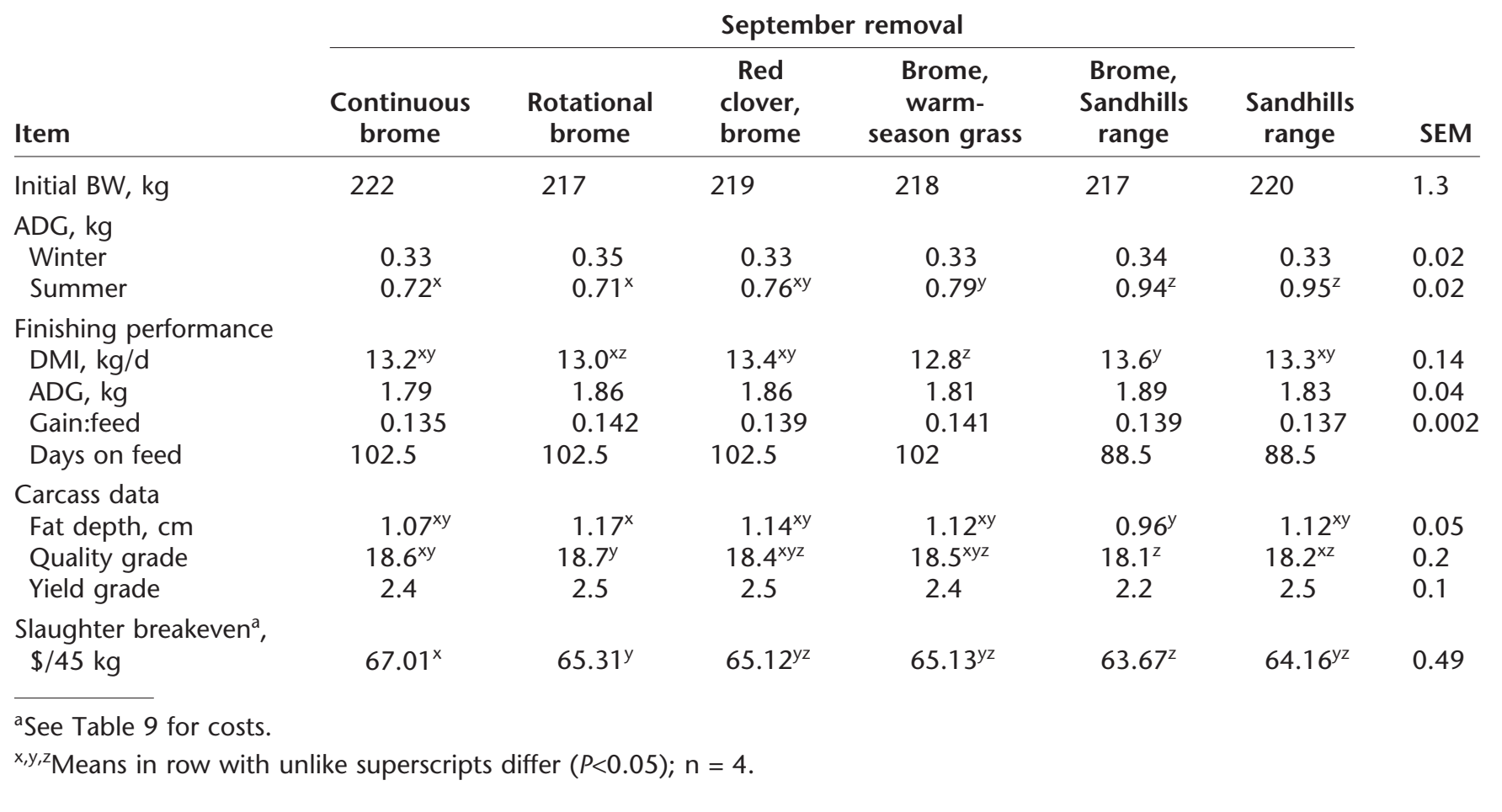

estimated that red clover made up 0 to $15 \%$ of the forage mass. In the fifth year, red clover was present at low levels for the first $30 \mathrm{~d}$ and $\mathrm{ab}$ sent thereafter.

Fall grazing ADG was $0.43 \mathrm{~kg} / \mathrm{d}$ in the fourth year and $1.11 \mathrm{~kg} / \mathrm{d}$ in the fifth year. Precipitation in late summer and fall provided more and better quality forage in the fifth year even though the summer was quite dry. Breakevens were similar for November removal treatments compared with similar summer treatments with September removal (data not shown).

Similar Treatments Among Years. Grazing systems that were similar across years (continuous brome or brome and warm-season grass) were pooled and analyzed. Cattle grazing brome and warm-season grasses had greater $(P<0.05)$ ADG during the summer grazing period compared with cattle grazing only brome (Table 11). During the finishing period, cattle in the con-
TABLE 11. Performance data pooled across years for cattle grazing continuous brome or brome and warm-season grasses.

\begin{tabular}{lccc} 
Item & $\begin{array}{c}\text { Continuous } \\
\text { brome }\end{array}$ & $\begin{array}{c}\text { Brome, warm- } \\
\text { season }\end{array}$ & SEM \\
\hline Initial BW, kg & 206 & 203 & 2.0 \\
ADG, kg & 0.31 & 0.31 & 0.01 \\
Winter & $0.72^{\mathrm{x}}$ & $0.82^{\mathrm{y}}$ & 0.01 \\
Summer & & & \\
Finishing performance & & $11.7^{\mathrm{y}}$ & 0.11 \\
DMI, kg/d & $12.2^{\mathrm{x}}$ & 1.63 & 0.03 \\
ADG, kg & 1.63 & $0.138^{\mathrm{y}}$ & 0.002 \\
Gain:feed & $0.134^{\mathrm{x}}$ & & \\
Carcass data & 1.07 & 1.07 & 0.05 \\
Fat depth, cm & 18.7 & 18.7 & 0.1 \\
Quality grade & 2.39 & 2.34 & 0.04 \\
Yield grade & & & \\
Slaughter breakeven ${ }^{\mathrm{b}}$, & $66.99^{\mathrm{x}}$ & $64.99^{\mathrm{y}}$ & 0.57 \\
\$/45 kg & & & \\
\hline
\end{tabular}

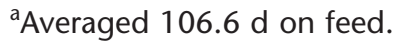

${ }^{\text {b }}$ See Table 10 for costs.

$x, y, z$ Means in row with unlike superscripts differ $(P<0.05) ; \mathrm{n}=10$. 
tinuous brome system consumed more feed $(P<0.05)$, gained similarly, and had lesser feed efficiencies $(P<0.05)$ than did cattle in the brome, warm-season grass system. No differences in carcass measurements were observed between treatments.

Cattle grazing brome and warmseason grasses had 3\% $(\$ 2 / 45 \mathrm{~kg}$ of BW) more desirable slaughter breakeven costs compared with cattle continuously grazing brome $(P<0.05$; Table 11). Cattle from the brome and warm-season grass system entered the finishing period with heavier BW and maintained this BW advantage throughout the finishing period.

Discussion. The success of a grazing system in this research is dependent on slaughter breakeven cost. Maximizing grazing gain at low cost may minimize breakeven. Therefore, this research was an attempt to maximize gains on forage and reduce the amount of grain and time cattle spend in the finishing phase. However, grazing a single forage for the entire grazing period may not allow for maximum grazing gain. Waller et al. (1986) reported that different forages have different rates and patterns of growth and that forage quality changes throughout the growing season according to temperature, moisture, and plant maturity. In addition, the seasonal distribution of growth or forage availability and forage quality should be balanced with the seasonal forage and nutrition demands of livestock (Waller et al., 1986). In eastern Nebraska, brome is the predominant forage available for grazing. However, brome is a cool-season plant, and quality and quantity of brome can decline during the months of June, July, and August. Therefore, the utilization of alternative or complementary forages is a method to balance the distribution of forage growth with the nutritional needs of livestock.

In this research, grazing brome and an alternative forage during the summer grazing period provided $\mathrm{BW}$ gains equal to or greater than those of cattle grazing only brome within most years. The only exception occurred during the third year in which cattle in the November removal, brome grazing group gained faster than did cattle on all other systems. This response was most likely due to a combination of a lesser stocking density and favorable weather for cool-season grasses during this year; presumably cattle on this treatment were able to continuously graze a high quality regrowth throughout the summer. However, cattle on other treatments were possibly limited in the amount of regrowth available because of a greater stocking density and weather that was less favorable for growth by warmseason grasses.

If environmental factors, such as moisture and temperature, influence the quality and quantity of forage available (Waller et al., 1986), a beef production system must be able to withstand annual environmental differences. Although summer gains during this study were different among years, differences among grazing systems should still be a reflection of the system's ability to maximize grazing gain. In addition, systems differing in grazing removal times may influence summer gains because of differences in stocking rates. Cattle in the late removal systems were given more grazing area, in theory, to sustain grazing gains until November or December.

Grazing Summer Annuals. Grazing brome then alfalfa, sudangrass, or warm-season grasses improved summer gains compared with grazing only brome (Year 1). Sindt et al. (1991) found no difference in BW gain for cattle grazing brome and sudangrass compared with cattle grazing only brome, which is inconsistent with our results. However, Sindt et al. (1991) concluded that cattle grazing only brome were more economical (less slaughter breakeven cost) than cattle grazing brome and sudangrass, which is in agreement with our results.

Grazing brome and alfalfa or sudangrass increased grazing gain compared with grazing only brome. Allen et al. (1992) reported similar results with calves grazing tall fescue and alfalfa that gained faster than calves grazing only tall fescue or tall fescue and red clover. However, total production costs among grazing treatments were not compared in that study (Allen et al., 1992). The added cost of producing both alfalfa and sudangrass in our study resulted in greater breakeven costs compared with grazing only brome or brome and warm-season grasses. The cost of producing sudangrass and alfalfa in our research was priced equal to the cost of cash-renting land for corn production plus planting costs. Therefore, the additional summer gain achieved by grazing alfalfa or sudangrass did not offset the additional cost of producing the forage.

Reducing cost of forage production by interseeding red clover in oats and charging land and production costs against the oats provides an alternative forage for grazing while keeping the cost of the grazed forage to a minimum. However, grazing only red clover has the potential risk of bloat. Providing poloxolene to cattle grazing legumes can offset the potential bloat problem, assuming that consumption is constant.

In the second year, systems that included grazing of red clover had the most desirable slaughter breakeven costs with grazing gains that were similar to other systems. However, bloat problems were experienced, which required removing heifers from the red clover pastures and placing them on brome pasture. Although grazing red clover as an alternative forage improved slaughter breakeven costs, the potential cattle loss attributable to bloat makes this system less desir- 
able because of extra costs of poloxolene supplement and labor to treat animals experiencing bloat.

If sudangrass or alfalfa were used in lands not suitable for grain production, then grazing costs would equal the cost of producing the forage (seed, planting, labor, etc.), which would lessen the slaughter breakeven cost of the system. Grazing red clover following harvest of a grain crop appears to have potential in improving production systems. However, potential problems with bloat in addition to increased labor costs for bloat management may reduce the benefits of grazing red clover. Grazing alfalfa, sudangrass, or red clover monocultures in addition to brome in the first two years either proved not economical or potential bloat problems made these systems less desirable.

Grazing Perennial Grasses. Conrad and Clanton (1963) concluded that ADG for steers were increased $40 \%$ when both cool- and warmseason grasses were utilized. In a ranking of cool- and warm-season grasses, Kaiser and Faulkner (1991) reported that brome and orchardgrass were the preferred grasses for spring and fall grazing, and Indian grass, Caucasian bluestem, and big bluestem were the preferred grasses for summer grazing. In this research, cattle in the early removal systems grazing brome and warm-season grasses during the summer grazing period provided gains equal to or greater than cattle grazing only brome in all years. In addition, slaughter breakeven cost for cattle grazing brome and warm-season grasses was more desirable than cattle grazing only brome.

In the fourth and fifth years, we utilized native grass resources available in the Sandhills of Nebraska to provide a mix of warm-season grasses as an alternative to establishing both cool- and warm-season grass pastures at one location. Grazing a native range with a wide diversity of plant species allows cattle to select higher quality forage (Coffey et al., 1989). In both years, BW gains for cattle grazing systems utilizing Sandhills range, either alone or in combination with brome grazing, were greater compared with gains by cattle grazing only brome and were greater than BW gains of cattle grazing brome and red clover or warm-season grasses in the fifth year. Below average rainfall in Year 5 probably reduced summer grazing gains for cattle in systems grazing brome, brome and warm-season grasses, or brome and red clover.

Grazing Interseeded Legumes. Interseeding red clover in brome pastures (Years 4 and 5) was an attempt to increase forage quality and quantity during periods when brome quality and quantity are declining. Several researchers have found that $\mathrm{N}$ fertilization can be eliminated when clovers are grown in grass mixtures (Marten, 1985; Vallis, 1976), which would reduce the need for $\mathrm{N}$ fertilization of brome pastures. In addition, rotational grazing of interseeded red clover and grass pastures is required to reduce the selective grazing of the cattle (Gerrish, 1991) and allow the red clover adequate time for regrowth.

Germination of red clover interseeded in brome patures was low in both years. Although improved gains for cattle grazing red clover and brome pastures were not seen in both years, results in Year 4 indicate that interseeding red clover in brome pastures has the potential for improving grazing gains compared with cattle grazing only brome. In agreement, Costa et al. (1995) concluded that the presence of red clover seeded into brome pastures increased overall quality of forage consumed by cattle.

Slaughter breakeven costs for cattle grazing red clover and brome pastures were similar to those for cattle grazing only brome pasture in Year 5. However, results from
Year 4 and pooled data from both years indicated that seeding red clover in brome pastures can reduce slaughter breakeven costs compared with those costs associated with cattle grazing only brome.

Grazing Fall Forages. Extending grazing past the summer grazing period has the potential for further increases in BW gain from forages, reductions in the amount of grain fed and time spent in the finishing phase, and improvements in reducing overall slaughter breakeven values. However, extending the grazing season will also increase interest cost charged against the animal; therefore, it is critical that fall grazing gains offset the increased interest cost.

Utilizing cool-season forages, such as brome, is common practice (Kaiser and Faulkner, 1991). However, several other alternative forages were utilized in this research. Seeding turnips in wheat stubble after harvest provides a highly digestibile forage for grazing while providing protection against soil erosion during the winter. However, adequate moisture during late July and August is needed for turnip germination and growth. Seeding rye in wheat stubble will provide the same benefits. However, unlike turnips, rye will not "winter kill" and, therefore, requires herbicide application in the spring, which increases the cost of producing rye. In addition, rye can be seeded later than turnips and, therefore, allows flexibility in the type of forage to seed in wheat stubble. Another alternative fall grazing forage is cornstalks following high moisture corn harvest.

Fall forage grazing gains were variable among years probably because of the variation in precipitation occurring among years.

The consistency of fall forage quality and quantity is a major consideration in fall grazing systems. If grazing gains are not sustained during the fall grazing period, the increased interest cost and lighter 
BW cattle entering the finishing phase will increase slaughter breakeven costs. The most consistent fall forage available for grazing may be cornstalks. In Year 5, gains for cattle grazing cornstalks were greater than gains obtained during the summer grazing period. However, these data are from only $1 \mathrm{yr}$; therefore, further research is needed.

When cattle enter the finishing phase, following a period of forage grazing, the majority of muscle growth has already occurred. However, sufficient finishing time is still required for cattle to deposit intramuscular fat to improve quality grade. Reducing time that cattle spend in the finishing period without reducing quality grade or fat thickness was one goal of fall grazing. In all years, cattle grazing fall forages were in the finishing phase for 16 fewer $d$ than cattle finished following summer grazing. In addition, the amount of grazing gain was negatively correlated with days on feed in the finishing period during all years, indicating that maximizing gain while on forage can reduce time spent in the finishing period.

In evaluating correlation coefficients among years, final finishing weight was negatively correlated with slaughter breakeven cost in all years, indicating that a greater final system weight would lower breakeven cost. Finishing period ADG influenced slaughter breakeven cost only in Years 1 and 4, whereas the amount of summer gain or total grazing gain influenced breakeven cost in 4 of the $5 \mathrm{yr}$. The amount of BW gain achieved during the fall grazing period had no influence on breakeven cost except in Year 1 where lesser fall BW gains increased breakeven cost.

In conclusion, grazing forages that maximized grazing gain re- duced overall breakeven cost of production. The most consistent forage combinations in increasing grazing gain and reducing breakeven cost were combinations of brome, warm-season grasses, or native range grasses. Grazing forages during the fall months has potential for further reductions in breakeven cost compared with grazing only summer forages. However, variable moisture for fall forages results in unpredictable grazing gains and subsequent breakeven costs in fall grazing systems.

\section{Implications}

The overall productivity of a beef production system can be improved by maximizing forage BW gain, while cost of gain is fixed, by grazing complementary summer and/or fall forages. Utilizing forages for beef production increases the sustainability of the beef industry by reducing amount of grain needed to finish beef cattle. In addition, highly erodable land that is not suited for crop production could be used in a forage grazing system, helping reduce environmental concerns of soil erosion.

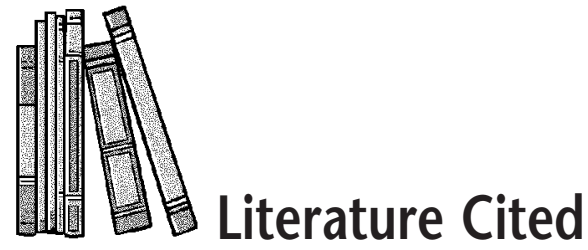

Allen, V. G., J. P. Fontenot, and D. R. Notter. 1992. Forage systems for beef production from conception to slaughter: II. Stocker systems. J. Anim. Sci. 70:588.

Brink, D. R., S. R. Lowry, R. A. Stock, and J. C. Parrott. 1990. Severity of liver abscesses and efficiency of feed utilization of feedlot cattle. J. Anim. Sci. 68:1201.

Coffey, K. P., J. L. Moyer, and L. W. Lomas. 1989. Comparison of forage sampling and drying methods for the estimation of forage composition. J. Anim. Sci. 67(Supp. 2):148. (Abs.)

Conrad, E. C., and D. C. Clanton. 1963. Cool-season, warm-season pastures needed. p 11. Nebraska Agric. Exp. Stn. Beef Cattle Progress Rep., Lincoln.

Costa, M., T. K. Klopfenstein, and D. H. Shain. 1995. Escape protein value of bromegrass/red clover pastures. Nebraska Beef Cattle Report MP62:16. Univ. Nebraska, Lincoln.

Gerrish, J. R. 1991. Biological implications of rotational grazing. Proceedings: American Forage and Grasslands Council, Georgetown, TX. p 2.

Kaiser, C. J., and D. B. Faulkner. 1991. Predicting animal performance for sequential grazing of various cool-warm-season perennial grass specie combinations. Proceedings: American Forage and Grasslands Council, Georgetown, TX. p 36.

Lewis, J. M., T. J. Klopfenstein, G. A. Pfeiffer, and R. A. Stock. 1990a. An economic evaluation of the differences between intensive and extensive beef production systems. J. Anim. Sci. 68:2506.

Lewis, J. M., T. J. Klopfenstein, and R. A. Stock. 1990b. Effects of rate of gain during winter on subsequent grazing and finishing performance. J. Anim. Sci. 68:2525.

Marten, G. C. 1985. Nutritional value of legumes in temperate pastures of the U. S. In Forage Legumes for Energy-Efficient Animal Production. Proc. Trilateral Worksh., Palmerston North, New Zealand. R. F. Barnes (Ed.). p 204. USDA, Springfield, VA.

Sindt, M. H., T. J. Klopfenstein, and R. A. Stock. 1991. Production systems to increase summer gain. Nebraska Beef Cattle Report MP 56:15. Univ. Nebraska, Lincoln.

Turgeon, A. O., Jr. 1984. Impact of high forage growing systems on finishing performance and compensatory growth. Ph.D. Diss., Univ. Nebraska, Lincoln.

Vallis, I. 1976. Nitrogen relationships in grass/legume mixtures. In Plant Relationships in Pastures. R. Wilson (Ed.). p 190. Iowa State Univ. Press, Ames.

Waller, S. S., L. E. Moser, and B. E. Anderson. 1986. A guide for planning and analyzing a year-round forages program. Univ. Nebraska Ext. Bull. EC 86-113. Univ. Nebraska, Lincoln.

White, T. W., F. G. Hembry, P. E. Humes, and A. M. Saxton. 1987. Influence of wintering weight change on subsequent pasture and feedlot performance by steers. J. Anim. Sci. 64:32. 